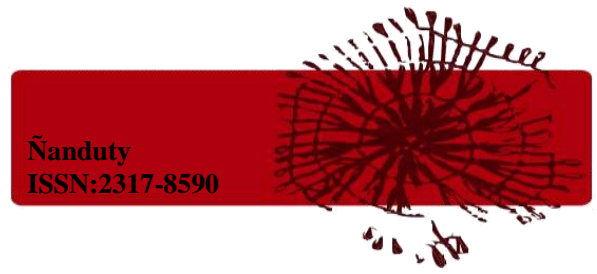

\title{
NOS TRANSFORMAMOS EM BRANCOS: NOTAS SOBRE A COSMOPOLÍTICA MBYA GUARANI
}

Vicente Cretton Pereira

\section{Resumo}

A partir de alguns contextos específicos de interação com os brancos (jurua) procuro investigar no presente trabalho como a cosmopolítica mbya está orientada. A partir de um irônico comentário de uma xamã mbya sobre sua (e de seu grupo) transformação corporal em brancos(as), busco entender as relações com o jurua como formas que os Mbya arranjam de experimentar um mundo que os ultrapassa e que, por isso mesmo, desperta seu desejo de modos diversos. Durante encontros lúdicos os Mbya estabeleciam certos laços com os brancos que podem resultar até mesmo em casamento, contudo a tensão que caracteriza a relação com o Outro algumas vezes é resolvida através da guerra ou de tentativas de familiarização.

Palavras-chave: Mbya Guarani; Cosmopolítica; Relações de alteridade

\begin{abstract}
Stemming from some specific contexts of relation with White people (jurua), this articles aim at investigating how and what mbya cosmopolitics is geared towards. From an ironic commentary of a mbya shaman about her (and her group's) bodily transformation into White people, it attempts to understand mbya relationships with White people as a way of experiment with a world that both overcomes them and figures out as an object of desire. During playful encounters, the Mbya engage into relationships that can even result in marital arrangements, but the tension characteristic to the relationship with the Other is also relieved, sometimes, via war or attemps to make one into kin.
\end{abstract}

Keywords: Mbya Guarani, Cosmopolitics, Alterity

\section{Introdução}

O texto a seguir é parte de um plano investigativo mais amplo acerca das relações entre os Mbya Guarani e os brancos (chamados por eles de jurua, ou no plural jurua kuéry). Em meu trabalho de campo, entre 2008 e 2013 na então aldeia de Camboinhas (Niterói, RJ), tais relações apareceram de diversas formas: desde a simples compra de artesanato feita por um visitante eventual até o casamento duradouro de moradores da aldeia, homens e mulheres, com jurua (algo que certamente pode ser caracterizado como 


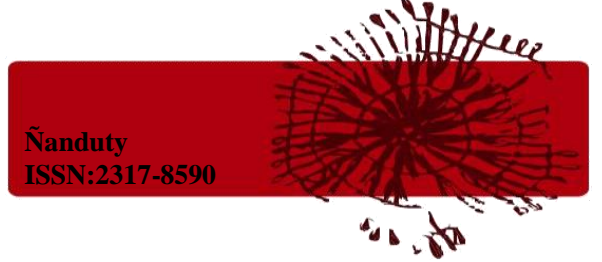

estrategicamente infrequente entre os Mbya de um modo geral). Nosso esforço será o de buscar compreender a lógica atuante, do ponto de vista mbya, quando se colocam em relação com os brancos: o que desejam? O que esperam? Como procedem para conseguir o que desejam? São algumas das questões que tentaremos responder adiante, a partir da etnografia de eventos cotidianos como partidas de futebol e cultos evangélicos, mas também de contextos onde a tensão inerente à relação com o Outro acaba sendo resolvida ou através da familiarização dos brancos ou por meio da guerra aberta com eles.

É preciso salientar, nesse sentido, que meu campo já começa com um evento que poderia ser bem mais trágico do que foi: um incêndio criminoso que consumiu a grande maioria das casas da aldeia, ocorrido em 2008. Sem vítimas, este acontecimento fez com que os Mbya experimentassem a hostilidade franca de seus novos vizinhos em Niterói (RJ). Já sublinhei que para eles o incêndio marcou um momento de "muito pavor" (Pereira 2010:90), mas que ao mesmo tempo não os impediu de seguirem com a luta para ocupar o local - um sambaqui ou, como diziam, um cemitério indígena. Diante de interesses imobiliários, preconceitos dos moradores de Camboinhas e a agressividade generalizada dos brancos os Mbya conseguiram manter seu deslocamento de Paraty (RJ) para Niterói, e após cinco anos já se mudaram novamente, desta vez para Maricá (RJ), abandonando a área na qual a maior parte de meu trabalho de campo foi realizado. Tentaremos a seguir fornecer subsídios para pensar a cosmopolítica mbya a partir de alguns contextos de relação com os jurua kuéry, a saber: encontros lúdicos como bailes de forró e partidas de futebol, encontros religiosos como cultos evangélicos, encontros em que a hostilidade foi fator decisivo e por fim abordaremos o processo de familiarização de brancos.

Antes de começarmos, uma pequena introdução acerca das pessoas de quem falaremos se faz necessária. O grupo de mais ou menos cinquenta pessoas é encabeçado pelo casal Lidia e Pedro. Seus filhos por ordem de idade são Iraci, Iracema, Tupã, Jéka, Zenico, Minju, Jaxuka e Kerexu, e foram eles (e seus cônjuges e filhos) os meus principais interlocutores durante os anos em convivi com os Mbya. Agái, filho de Iracema, e Vera, marido de uma filha desta, foram especialmente próximos durante o trabalho de campo. Aparecerão também ao longo do texto personagens de Araponga, aldeia de Augustinho, que é irmão de Joventina (mãe de Lidia), são eles: seus filhos Nino e Nírio. 


\section{Jurua re rojepota: nós nos transformamos em brancos}

Durante meu trabalho de campo eram comuns os eventos semanais de forró, no qual a atração principal era a banda Moleques da Pisadinha formada por jovens moradores da aldeia. Com o crescente sucesso deste evento a banda passou a ser procurada por micropromotores de shows tanto para levá-la para tocar em outros lugares como também para utilizar o espaço da aldeia para outros tipos de shows: foi o caso do Reggae na Oca, que ocorreu mensalmente durante quase todo o ano de 2012. O promotor deste evento, chamado pelos Mbya de Rasta, conseguiu realizá-lo regularmente apesar da série de desavenças ou mal-entendidos que se acumulou entre ele e os índios. Nada muito drástico, contudo significativo para nosso propósito neste trabalho: particularmente em uma ocasião, a atitude de Rasta se traduziu em desrespeito aos deuses.

Ele havia chegado, como de costume antes da hora marcada para o evento, a fim de arrumar o salão e seu stand de vendas. Ao ligar os amplificadores potentes da banda da aldeia quase no máximo volume, Rasta começou a causar certo mal estar nos Mbya. Não que esta fosse uma atitude particularmente anormal, somente o era naquela noite, pois estava relampeando. Como o som alto feria diretamente a etiqueta mbya acerca de momentos em que os Tupã estão caminhando (durante tempestades, chuva de relâmpagos, trovoadas, etc) - se espera então que as pessoas permaneçam sentadas, prestando atenção, fumando o cachimbo, etc -, logo os Mbya começaram a comentar entre si, elegendo alguém para ir lá falar com ele: eu. Sem dar muita explicação avisei ao Rasta que ele teria que desligar o som, mas ele se recusou. Depois foi Minju, também sem sucesso. Tivemos que nos mobilizar num grupo de cinco pessoas entre as quais a autoridade máxima da aldeia: Lidia, Jéka, eu, Minju, Kerexu e ainda assim não foi nada fácil. Mesmo explicando que era por causa dos relâmpagos, Rasta dizia que eles estavam passando muito longe, fez uma contagem no relógio alegando que cada segundo seria um quilômetro de distância: ele contou nove. Minju comentou em mbya conosco, "o que são nove segundos para Nhanderu?". Até que Lidia, já perdendo a paciência falou para ele, tem que desligar um pouqunho, pra respeitar deus mesmo, e só então Rasta foi desligar.

Temos aqui um pequeno exemplo do que Viveiros de Castro chama de "doutrina do equívoco" (Viveiros de Castro 2015:87) em referência ao perspectivismo indígena: a comunicação entre os Mbya e Rasta só pode efetivamente acontecer quando ambos os 


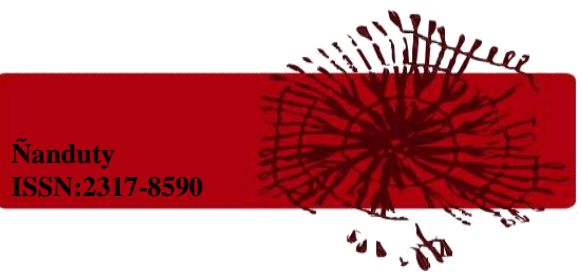

lados exploraram simultaneamente a natureza do Outro, ou melhor o que era a Natureza para o Outro, ou melhor ainda (e do ponto de vista dos Mbya) o que a nossa Sobrenatureza é para o Outro e assim por diante. Em todo caso estamos diante de um evento que, principalmente para o antropólogo, é duplo: "Diríamos que aquilo que os humanos apreendem como caça, os porcos apreendem como guerra", comenta Lima (1996:34) sobre a caça aos porcos praticada pelos Yudjá, "entretanto esta é uma formulação equivocada, pois pressupõe um único e mesmo acontecimento". O que para Rasta é um fenômeno natural passível de ser medido em segundos, sendo por isso controlável, para os Mbya é a caminhada de um coletivo de hiper-pessoas, os Tupã, aos quais respeitam e temem, mas dos quais também recebem cuidado e proteção. Porque o mundo segundo os Mbya é irredutível ao mundo tal e qual Rasta (e por extensão, os jurua kuéry em geral) só pude ver como uma boa e significativa piada a seguinte frase dita por Lidia em outra ocasião: "nós já não nos acostumamos/alegramos mais na floresta, nos transformamos em jurua" (ka'aguy re ndorovy'a véi ma, jurua re rojepota $)^{1}$.

Embora cômica a afirmação acima poderia se encaixar em um campo de pesquisa atualmente bastante conhecido sobre as teorias indígenas acerca do "virar branco". Como lembra Kelly (2005:212): “muitos etnólogos já observaram que os mundos vividos indígenas apontam mais para um constante 'devir' que para um 'ser' estável”, e o próprio autor considera o fenômeno do "virar branco" (um caso particular do "devir-Outro" ameríndio) como bastante difundido na região amazônica, sendo produto de um contato interétnico diversificado, que ocorre em cenários diversos. Mas diferentemente dos Yanomami que dizem estar virando brancos (napë) ou dos Kanamari que dizem estar virando Funai (Costa 2016) os Mbya não afirmam de um modo geral que estão se tornando jurua. Há, pelo contrário, toda uma estratégia de diferenciação que vai desde a evitação de casamentos com brancos até o temor em se alimentar junto a eles. O que se ouve na

\footnotetext{
${ }^{1}$ Lidia fez esse comentário efetivamente com bom humor e como desculpa para não chegar em Araponga, aldeia localizada em uma área de densa floresta em Paraty (RJ). Na ocasião aproveitava a carona deles, que em seu carro iriam até a casa de Iraci, que é casada com um jurua e reside na área rural da vila de Patrimônio, relativamente perto de Araponga. Então, só me levaram até a metade do caminho para a aldeia, tanto porque daí em diante a estrada piora muito quanto porque não estavam, talvez, preparados para uma chegada em uma aldeia com cujos habitantes o pessoal de Camboinhas guarda uma ambígua relação de proximidade (pelo parentesco) e afastamento (por mútuas acusações de feitiçaria etc). Em resumo de tudo isso, Lidia sorriu e explicou que tinha medo de ir pelo fato de Araponga estar localizada no meio do mato, algo que para mim só podia ter um sentido cômico. Afinal, eu sabia que ela e sua família haviam morado ali por quase dez anos.
} 


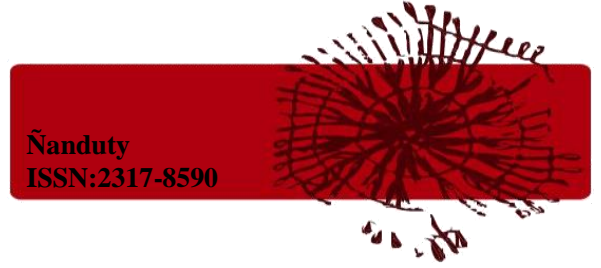

verdade, em um neologismo dos Mbya do Rio Grande do Sul, é que o jurua já nasce jepotado ${ }^{2}$.

É com esse verbo, -jepota, que Lidia fala da transformação em branco, contudo na maioria das vezes ele é utilizado pelos Mbya para se referir à transformação de uma pessoa (mbya) em animal e a possibilidade de que isso aconteça em direção a um corpo jurua é justamente o elemento engraçado da colocação de Lidia. Trata-se de um processo de adoecimento tanto comum quanto tratável de modo eficaz somente através do xamanismo. Pode-se viver com a doença durante muito tempo caso não se procure um xamã eficiente e embora a pessoa que ora esteja passando por este processo de transformação seja um perigo real para seus corresidentes, diz-se que só se vira realmente animal depois que morre (casos em que o cadáver precisa ser queimado). A ênfase contudo é no processo em si e não em sua conclusão, o que nos remete ao que diz Costa (2016) sobre o aspecto continuativo do "virar Funai" kanamari: "aponta o decorrer de uma transformação e não resultado ou a conclusão" (Costa 2016:102). Neste sentido poderíamos falar de um "devir jurua" (isto é, uma relação de fascinação e desejo pelo jurua e seu mundo) para os Mbya Guarani de um modo geral, buscando sobretudo pôr em relevo as formas pelas quais o pessoal de Camboinhas era afetado por esta relação de modo notável, a começar pela disposição que homens e mulheres tinham em casar com brancos(as). Como o casamento aparentemente é a forma última desta (não) transformação, começemos por analisar alguns contextos lúdicos de interação com os jurua conforme observei durante o trabalho de campo.

\section{O futebol}

Partidas de futebol eram diárias em Camboinhas e é interessante notar que aconteciam quase sempre no final da tarde. Neste mesmo horário, como prelúdio à entrada de todos na casa de reza para o ritual noturno, realizava-se (e ainda se realiza em outras aldeias) a dança dos guerreiros (xondáro), de modo que comecei a pensar no futebol como uma espécie de substituto desta. Em Araponga, onde o futebol era pouco comum, foi onde mais vi a dança dos guerreiros acontecer ao final das tardes, principalmente durante momentos cerimoniais (batismo das crianças, do milho, do mel, etc). Delgado (2010:130)

\footnotetext{
${ }^{2}$ Mariana de Andrade Soares, etnóloga dos Mbya da região, quem me deu esta informação em comunicação pessoal.
} 


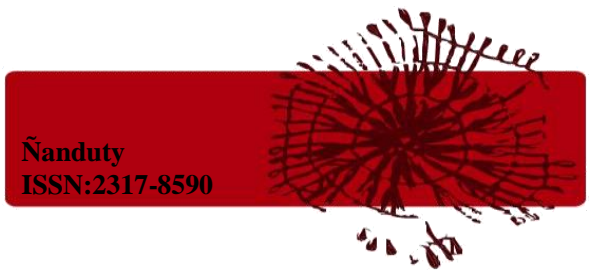

que para os yanomami, povo notadamente conhecido pelas guerras de vingança que resultam quase sempre na morte do inimigo:

El fútbol permite (...) competir, rivalizar, medirse en el domínio de una actividad no tradicional que les resulta divertida y se ha instalado o lo está haciendo en la ocupación cotidiana del tiempo de muchos, especialmente niños y jóvenes. Esta nueva actividad aporta a los yanomami una nueva forma de agonismo, um agonismo que lejos de producir sangre y muerte, se desarrolla en grupo, en clave pacífica y produce sensaciones placenteras.

Evidentemente, não creio que se possa falar em sangue e morte para o material mbya, mas me parece igualmente claro que os testes físicos exigidos nas danças xondáro (saltar, esquivar-se, correr etc) - testes que visam à formação de guerreiros e guerreiras encontram equivalente a altura nas partidas de futebol diárias.

O futebol também costumava ser o modo preferencial através do qual jovens do sexo masculino começavam amizades com jurua kuéry que moravam ou circulavam nas vizinhanças da aldeia: após um encontro casual vinha o convite, vai lá de tarde pra gente jogar bola. Com o tempo, os jurua que frequentavam regularmente a aldeia para jogar, acabavam chamando-os para jogar fora. Participaram assim de competições futebolísticas em bairros e até municípios vizinhos. Alguns dos jogos contra jurua (e contra outros Mbya também, como se verá) eram apostados em dinheiro ou cervejas, o que era, para dizer o mínimo, um forte motivador para a partida. Aliás, mesmo em jogos cotidianos, quando queriam colocar mais emoção na partida, apostavam uma garrafa de refrigerante, ou algumas latas de cerveja (que seriam, na maioria das vezes, compradas no próprio bar da aldeia).

Tive a oportunidade de acompanhá-los algumas vezes à aldeia de Paraty Mirim para eventos que envolviam futebol e, às vezes, também, forró, o que exigia nosso pernoite. Na primeira vez em que uma viagem destas ocorreu, eles haviam se mudado de Paraty Mirim há pouco tempo, e esta aldeia era um ambiente muito familiar para eles. Naquela ocasião estava acontecendo um campeonato de futebol com vários jogos e muitos Mbya de outras aldeias. O clima era de festa. Nos dirigimos para o campo e após os noventa minutos, e mais os pênaltis, saímos vitoriosos. Nino e Nírio que jogaram no nosso time, nos levaram para a comemoração da vitória num bar na vila de Patrimônio. Ali 
Nandu

4.

compraram sanduíches, biscoitos, cigarros e cerveja, de modo que pouco (ou quase nada) dos cem reais ganhos na partida voltou para Camboinhas.

Futebol e forró apareceram, durante o trabalho de campo, como contextos privilegiados de atualização de relações de afinidade, seja em relação a afins reais (como era o caso dos Mbya de Paraty Mirim $^{3}$ ), seja em relação a afins virtuais, caso dos jurua (se bem que alguns jurua passariam a afins reais rapidamente em Camboinhas). O futebol mbya estaria assim menos para a reciprocidade generalizada do futebol urarina - que caminharia em direção a uma centralização e unificação das comunidades urarina por meio da ritualização da modernidade através do futebol -, como observado por Walker (2013:33), e mais para a captura estratégica de recursos materiais e simbólicos fora do socius: "a atração e a captura de elementos estranhos ao mundo Mbyá parece ser o objetivo principal do investimento em relações com determinados juruás, por meio da realização regular de eventos como os forrós e os jogos de futebol”, observa Migliora (2014:25). Já argumentei alhures, ainda que em nota, (Pereira 2016:758) que o problema da afinidade na Amazônia (cf Viveiros de Castro [2002]2011:87-180) poderia ser extrapolado para fora desta grande área etnográfica, de modo que a construção da consanguinidade entre os Mbya seria doravante um processo interminável de despotencialização da afinidade e da diferença. Estaríamos assim em uma vertente não amazônica da economia simbólica da alteridade (Viveiros de Castro [2002]2011:335), e os símbolos em circulação passam não só pelo terreno lúdico do futebol e do forró, mas também pelo terreno da guerra e da religião, como se verá.

\section{Cultos evangélicos}

Foi através do futebol, que o culto evangélico encontrou as primeiras possibilidades de entrada no cotidiano da aldeia. Tudo começou quando Roberto, jogador de futebol profissional e morador do bairro de Camboinhas começou a se aproximar dos Mbya, os quais logo se fascinaram com a possibilidade de "se fazerem amigos" (-nhemoirü) de um jogador famoso. Contudo, ele era também pastor de uma igreja evangélica localizada próximo à entrada do bairro, e embora não tivesse deixado claro desde o início de sua relação com os Mbya, sua chegada na aldeia e a vontade de se aproximar deles tinham

\footnotetext{
${ }^{3}$ Já que Iracema, Minju, Jéka e Agái (filho da primeira) haviam se casado com pessoas do grupo de Miguel, cacique desta aldeia.
} 
-

ISSN:2317-8590

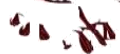

como objetivo (talvez principal) a evangelização: sua missão, como diria posteriormente, era trazer a "palavra de deus para os índios".

Ao frequentar a aldeia para jogar futebol, Roberto procurava sempre fazer uma oração antes de começar as partidas, e nestes momentos me chamava à atenção o modo como os Mbya (os jovens que iam jogar, neste caso especificamente) participavam, com os olhos fechados, em silêncio e aparentemente concentrados nas palavras do pastor. Disto para o culto semanal (que aconteceu com certa regularidade durante o ano de 2012) foi preciso apenas um passo ${ }^{4}$. Mas o culto não compunha, segundo minhas impressões, um ambiente dos mais confortáveis para os Mbya, embora eles afirmassem, de uma forma consensual, que era bom (ha'eve) escutar o que o coletivo de crentes (crente kuéry) tinha a dizer sobre Nhanderu ("nosso pai") e Tupã ra'y ("filho de Tupã”), isto é, Jesus. Notei sempre que os pastores não tinham a menor preocupação em ajustar sua linguagem para um público composto por uma maioria de pessoas cuja língua materna não era o português, bem como não tinham o menor interesse ou disposição para escutar o que os Mbya achavam em relação aos assuntos tratados. Desta forma os conceitos, dogmas e pregações, ao que parece, soavam certamente vagos demais para terem algum efeito minimamente conversivo: o culto parecia ser algo monótono e entediante para os Mbya. Mas, mesmo assim, eles seguiam afirmando seu desejo pela presença semanal dos crentes.

Durante muito tempo, estas reuniões aconteciam toda terça-feira, no salão de entrada da aldeia, o mesmo no qual se localizava o bar e onde a cada domingo se apresentavam os Moleques da Pisadinha. Assim, a cada terça feira, um pouco antes das oito horas, Pedro preparava o salão: tampava o bar com um pano, e enfileirava as cadeiras de plástico, posicionando-as de frente para o palco no qual os Moleques se apresentavam nos domingos, o qual fazia às vezes de púlpito. Geralmente íamos na casa de reza antes de os crentes chegarem, ainda que rapidamente. A chegada do pastor e seus companheiros era sempre impactante para mim, já que eu insistia em notar seu etnocentrismo e sua falta de bom senso nas relações com os Mbya, de modo que anotei em meu caderno de campo em dezembro de 2012, "parece que a criatividade guarani é nula aos olhos deles". Porém, os Mbya pareciam não compartilhar de minha revolta de modo que não tive outra saída senão sentar-me e participar, como todos os demais. De qualquer forma, parecem haver mais

\footnotetext{
${ }^{4} \mathrm{O}$ fato de uma filha da Lidia (a mais velha, Iraci) ser evangélica também facilitou, de alguma forma, a aproximação do pastor e de seu grupo, já que ela, embora não morasse em Camboinhas, passava longos períodos lá, e sempre que podia estreitava relações com Roberto e os fiéis de sua igreja.
} 


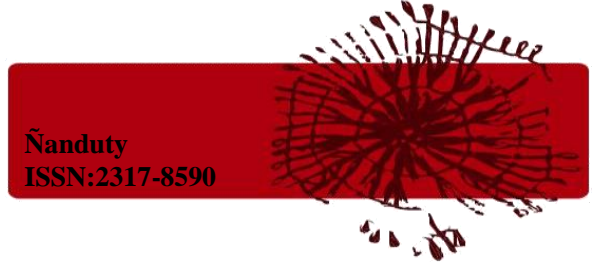

nexos entre os estilos de criatividade (sensu Wagner 2010) evangélico e Mbya do que se supõe à primeira vista, afinal, não por acaso Lidia confirmava as palavras dos pastores e missionários com um anhete ko ("verdade mesmo"), expressão de uso comum durante discursos públicos e rituais, principalmente nas casas de reza.

Com o tempo notei que a postura desejada por Lidia durante os cultos era quase que a mesma daquela que é esperada durante os rituais na casa de reza, "eu quero que vocês se sentem e prestem atenção" (aipota pende kuéry peguapy, pejapyxaka), dizia ela um pouco antes das reuniões. Em uma ocasião especificamente ela se dizia assustada com uma briga que ocorrera na aldeia durante um forró, e na qual inclusive Pedro se envolvera, de modo que este foi, então, convocado pelo pastor a ir ao púlpito receber uma benção. Pedro comentou após o término do culto, já com um copo de cerveja na mão, eles querem que eu vire crente, mas virar mesmo eu não viro não. Não estamos, de fato, no terreno da conversão tal como estudado por Vilaça (2007; 2008), Capiberibe (2007) ou Pereira (2012) entre muitos outros, mas certamente no da "crítica xamânica ao cristianismo" para usarmos a expressão de Pierri (2014):

Tudo o que existe na terra, encontra seu equivalente originário nos domínios celestes: a Bíblia, que o criador deu aos Brancos para enganálos, cegando a sua capacidade de visão dos espíritos através do papel, não é diferente. Tupã Ru Ete, a divindade que personifica a multiplicidade dos espíritos provenientes dessa região do cosmos, é quem detém o livro mara e' $\tilde{y}$, no qual ele escreve tudo o que está acontecendo nessa terra, sob o desmando dos brancos. A Biblia Cristã não é mais que uma imagem transformada desse livro (oanga kue), e guarda a marca de uma visão incompleta sobre o cosmos e os espíritos que o povoam. É por essa razão que, dentro de um espírito de tolerância absolutamente perspectivista, os Guarani não consideram o cristianismo propriamente falso, mas em certa medida míope (Pierri 2014:17).

Seguindo as orientações de Lidia aprendemos a frequentar os cultos "apenas por respeito" (nhemboete gui rei) pois os crentes efetivamente "não sabem" sobre Nhanderu: "não sabem sobre o pai verdadeiro de Tupã, não usam cachimbo, mas eu sei, o pai verdadeiro de Nhamandu usava cachimbo e tabaco", explicava ela, de modo que aos crentes era atribuído meramente um tipo de saber residual sobre o filho de Tupã, Jesus, ou Tupã ra’y.

Contudo, algumas vezes o culto trazia à tona certas emoções que ultrapassavam as costumeiras banalidades ditas pelos pastores e missionários e isto acontecia, 


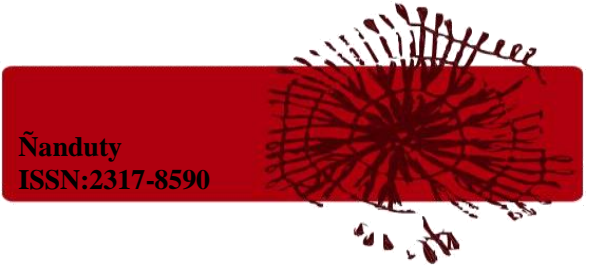

principalmente, quando algum Mbya se deixava efetivamente afetar pela proposta. Numa noite de outubro de 2012, Tupã quase levou os crentes às lágrimas ao relatar a história de Jurua'i, seu segundo filho considerado por ele, na linguagem evangélica, como um "milagre". Tudo começou quando o pastor perguntou se alguém gostaria de dar o seu testemunho, e Tupã, que não é evangélico, se levantou, foi até o palco, pegou o microfone e começou a relatar a história de Jurua'i, primeiro em Mbya (o que ainda não havia acontecido em nenhum outro culto antes deste) e depois em português, a mesma história. Nos dois modos, a audiência mbya estava notavelmente envolvida, acompanhando e atestando a veracidade do relato com as costumeiras exclamações de anhete ko.

Dizia então Tupã que quando Jurua'i tinha seus dois ou três anos esteve muito doente, e teve de ser levado para a casa de reza onde os pajés o rezaram demoradamente, mas não deram uma solução para o problema, de modo que, em algum momento daquela madrugada, o coração do menino efetivamente parou de bater. Então, os pajés disseram para Tupã, "agora é com você e Nhanderu”, de modo que ele saiu da casa e foi para o pátio em frente à casa, acendeu uma fogueira e pediu para Deus para que, se aquela criança tivesse sido enviada para alegrar os parentes (sua família, entenda-se), então que Ele fizesse viver novamente, não para ele, Tupã, mas para a família ${ }^{5}$. Então, já quase amanhecendo, Lidia ofereceu mbojape rata $\tilde{a}^{6}$ e mel para Tupã que estava sentado ao lado do corpo da criança. Em lágrimas, começou a comer o mbojape, momento no qual percebeu um movimento no corpo antes inerte: Jurua'i acordava querendo comer um pedaço de pão.

Em seguida ao milagre de Jurua'i, ele também contou brevemente o caso de Kuaray, seu sobrinho, que ficou muito doente quando criança, mas depois se curou, e também citou de maneira semelhante o adoecimento de Minju. Ao que parece há uma certa incidência de casos de "quase morte" que se seguem a recuperação da pessoa, os quais podem ser lidos tanto como histórias sobre enfeitiçamentos de diversas naturezas, quanto como "testemunhos" (para usar uma palavra do repertório evangélico) de como deus atua na vida dos Mbya: uma chave xamânica de um lado, de outro uma linguagem evangélica, mas ambos para falar dos mesmos fenômenos. É interessante notar que Augustinho, de Araponga, chegou a me dizer que gostava muito dos crentes explicando que eles seriam

\footnotetext{
${ }^{5}$ Por essa razão, explicou-me posteriormente, não era ele quem cuidava do menino, mas sim sua mãe, Lidia

${ }^{6}$ Pão feito com farinha de milho e cinzas.
} 


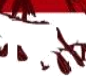

mesmo como os Guarani: "não se embriagam[com bebidas alcoólicas], não fumam cigarro". Ele gostava de se dizer, ele mesmo, crente, embora não frequentasse regularmente nenhuma igreja, e mantivesse as atividades diárias na casa de reza de sua aldeia com muito cuidado e dedicação. Aparentemente aquilo que para nós pode parecer uma relação de mútua exclusividade - xamanismo e cristianismo, forró e religião, sagrado e profano, etc - é visto pelos os Mbya através de uma solução de continuidade, em uma lógica que define para a diferença um lugar constitutivo. Certa vez, o pastor Roberto comentou com Minju, provocando-lhe certamente, pensa que é só tocar um forró aqui e pronto?, sai dessa iáca cara!, mas longe de se sentir atingido, ou sequer cobrado, Minju comentou comigo posteriormente que Nhanderu dá para cada pessoa um dom específico e o dele é o de tocar forró, de modo que ao fazê-lo, estaria procedendo conforme Nhanderu mesmo colocou para mim, como disse. O cristianismo está assim contido no xamanismo mbya tanto quanto a habilidade para tocar forró pode estar a serviço de uma vocação dada pelos deuses.

\section{O forró}

Como já comentei, no mesmo lugar no qual se desenrolavam os cultos também aconteciam, os forrós e os reggaes, eventos que tinham basicamente como publico alvo jurua kuéry, moradores de bairros próximos a Camboinhas. $\mathrm{O}$ forró tinha um componente especial por ser levado a cabo por uma banda composta por quatro filhos de Lidia. Eles possuem cd's gravados em estúdio e gozam de relativa popularidade, pelo menos entre as demais aldeias mbya (pelas quais eventualmente são contratados para fazer shows), o que conseguiram graças à divulgação das músicas e vídeos pela internet (via facebook, site palco mp3 e semelhantes). Dizem que o talento para a música os acompanha desde muito cedo, sendo que desde crianças já imitavam os cantores de sertanejo e forró, bem como brincavam com instrumentos como violão, sanfona, teclado, etc. E se eles faziam shows de forró desde que estavam em Paraty Mirim, foi somente em Camboinhas que o formato de banda se delineou de uma forma mais sistemática, com uma formação fixa e apresentações regulares.

Os eventos de forró (ou bailes) parecem ser comuns, de uma forma geral, em aldeias mbya, sendo que os pude observar também em Paraty Mirim e Estiva (Rio Grande do Sul). Mas se, via de regra, o forró acontece nas aldeias mbya com a utilização de som 


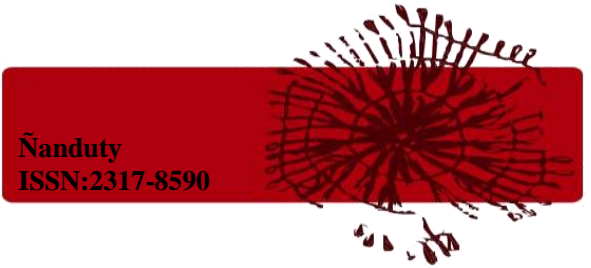

digital (isto é, sem a presença de uma banda tocando ao vivo) e com a predominância (senão exclusividade) de participantes mbya, em Camboinhas acontecia justamente o contrário: havia uma presença maciça de brancos e a apresentação de uma banda composta por Mbya. Dois importantes aspectos da vida dos Mbya com quem convivi estavam em jogo com o investimento na regularidade destes eventos (que se deu mais ou menos a partir de meados de 2010): primeiro, o prestígio de serem vistos, não apenas localmente (se destacando rapidamente diante de outras bandas de forró, sendo inclusive chamados por organizadores de eventos para fazer shows fora da aldeia, em Camboinhas, Piratininga e outros bairros da cidade), mas "nacionalmente", pelo menos no âmbito das aldeias mbya, como uma banda profissional; segundo, o fator econômico, já que era durante os forrós que o bar mantido na aldeia por Lidia e Pedro vendia mais. Basicamente se investia na venda de cerveja, comprada anteriormente num supermercado próximo por um determinado valor, ao qual se acrescentavam três ou quatro reais a serem lucrados. Também vendiam algumas bebidas quentes como cachaça e conhaque, mas nada que se equiparasse ao ganho que obtinham com a venda de cerveja.

Costumeiramente durante os forrós Lidia se sentava com suas duas filhas mais novas Jaxuka e Kerexu, as únicas então solteiras (embora vez por outra Iracema e outras mulheres, casadas com filhos de Lidia também aparecessem) nos fundos do salão, na parte oposta ao palco. A xamã buscava administrar com conversa e cerveja a relação entre suas filhas e seus eventuais pretendentes. Um destes acabou por se casar com Iracema e enquanto durou esta relação insistia em não deixar sua esposa dançar com outros homens durante os forrós. Esta pretensão de controlar a esposa (quando se dizia que ele era

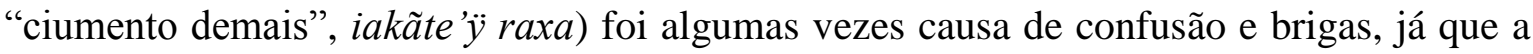
etiqueta mbya do forró é a de jamais recusar uma dança, atitude que seria facilmente enquadrada na esferea da antisociabilidade?: "todas as mulheres, casadas ou não, que passavam pela porta que ligava o pátio interno ao salão deveriam dançar com quem as chamasse", observa Migliora (2014:100) em relação ao mesmo contexto etnográfico. Na verdade o forró só parece fazer sentido a partir do ponto de vista da dança, de modo a propagar a animação e a alegria nos presentes. Pedro (e eventualmente alguns de nós,

\footnotetext{
${ }^{7}$ Durante um forró em Paraty Mirim, minha esposa (que tinha ido conosco nesta ocasião) segurou uma neta de Lidia pelo braço vendo que um homem muito bêbado e aparentemente agressivo a tinha tirado para dançar. Disse para ela então, fica aqui ao que ela respondeu, igual bicho?. Se falamos em antisociabilidade, vê-se que sua associação com o -jepota é imediata, no pensamento mbya.
} 


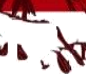

jovens do sexo masculino), por sua vez, trabalhava no bar, vendendo cerveja, recolhendo garrafas das mesas e administrando o dinheiro.

Num dos primeiros shows da banda de Camboinhas em Paraty Mirim, reparei na ansiedade com que nos aguardavam os Mbya desta aldeia: enquanto nosso ônibus chegava as crianças gritavam em coro (em português), che-ga-ram, che-ga-ram!. Logo após subimos até a entrada da aldeia onde o Cacique Miguel mandou que nos trouxessem água quente em uma garrafa térmica, cuia para tomar chimarrão e uma grande panela contendo arroz, feijão e carne, misturados - nosso almoço. À noite o forró começou com um repertório de músicas em mp3 do computador de Minju, e talvez lá pela meia noite os Moleques da Pisadinha começaram o seu show. O salão estava lotado e a cada música começada e terminada, os casais encontravam-se e separavam-se: era como se a cada nova música, se iniciasse, por direito, uma nova dança, com um par diferente. Alguns meninos menores prestavam atenção nas habilidades de Minju no teclado, imitando-o de brincadeira, mas revelando uma grande admiração. Na verdade o que mais me chamou a atenção durante esta viagem foi o prestígio de que gozavam os integrantes da banda de Camboinhas como músicos habilidosos.

\section{À guerra}

Já mencionei acima que o futebol poderia atuar em Camboinhas como espécie de substituto para a dança dos xondáro. Cabe agora explorarmos um pouco mais esta categoria, mostrando quem são e o que fazem. Segundo Macedo (2013:204) "os xondáro em geral são aqueles que hoje estão na linha de frente nas relações institucionalizadas com os brancos". De modo semelhante ao que Pissolato (2007:339) descreve uma dita função xamânica distribuída entre os adultos, esta rápida definição do grupo dos xondáro aponta igualmente para uma função à qual talvez a maioria dos adultos mbya possa eventualmente assumir. Os Mbya se consideram de modo geral como guerreiros e guerreiras, sendo inclusive as crianças tratadas como xondáro'i e xondária'i desde bem cedo e principalmente nos contextos rituais da casa de reza. Contudo, Macedo (2011) ao propor uma descrição da cosmopolítica mbya a partir de vetores porã (verticais, que ligam os Mbya aos patamares celestes dos divinos) e vai (horizontais, que os ligam aos demais seres desta Terra dita vai, imperfeita, má, perecível, etc) põe em relevo que, para começar há uma diferença importante entre o trabalho do xamã e o do guerreiro: enquanto o primeiro 


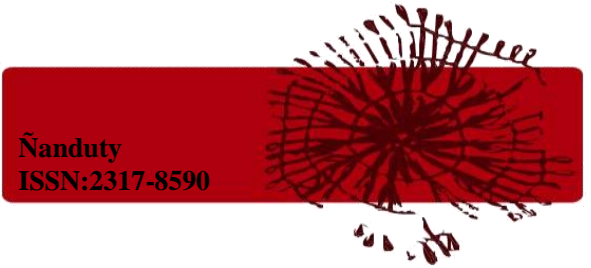

busca atualizar as relações com as divindades a fim de extrair doenças de seus pacientes, o segundo incorpora relações com potências vai desta Terra como animais, donos, espíritos dos mortos, etc. Segundo interlocutor de Macedo, Vera Mirï:

\begin{abstract}
Antigamente já existia xondáro. Tinham várias funções, vários comandos. O primeiro comando só cuidava da guerra, a parte externa, contra outras aldeias e contra os brancos também. (...) Mas os xondáro que cuidam de fora da aldeia não podem entrar na opy[casa de reza], porque já foram para guerra, são autorizados a matar, são eles que cuidam da parte feia da aldeia. Então não são autorizados a entrar na opy. Eles são protegidos por vários espíritos, têm a habilidade e a inteligência própria para isso. Desde criança são treinados pra isso. Geralmente são protegidos por itaja e kaguyja, porque itaja dá a eles o poder da proteção e kaguyja o poder de camuflar na floresta (Macedo, 2013:38).
\end{abstract}

Timóteo Popygua, então cacique da aldeia paulista Tenonde Porã, afirma que a dança dos xondáro era tão perigosa "que chegavam até a morte, pois os xondáro eram treinados com os espíritos dos mortos. E existiam muitos na floresta, eles até desafiavam, entravam em conflitos" (Delane, Almeida e Samuel dos Santos 2008 apud Macedo 2013:34). É difícil delinear as características exatas dos grupos de xondáro do passado se comparados, por exemplo, aos povos chaquenhos estudados por Clastres ([1980]2004:273316) nos quais seriam visíveis os grupos separados de guerreiros, mas sabemos por exemplo que nos anos 1980, quando ocorreram várias migrações mbya da região Sul e aconteceram as primeiras demarcações de Terras Indígenas no Estado de São Paulo “formaram-se grupos de xondáro em algumas aldeias (...). No Silveira, eram responsáveis pela defesa do território contra caçadores, palmiteiros e as motosserras dos jurua que queriam implantar loteamentos" (Macedo 2013:35).

Observei a formação destes grupos em Araponga durante rituais de batismo (nhemongarai) que duravam dias, e nestas ocasiões o grupo de jovens designados como xondáro se ocupava principalmente de admoestar crianças menores e participar ativamente das cerimônias noturnas: vigiavam as entradas da casa de reza, usavam o cachimbo com intensidade, faziam soar os pequenos bastões rituais (popygua) e assim por diante. Foi em Camboinhas que a sombra da guerra de fato se aproximou mais de nós, e sempre em contextos de relação com brancos. Aliás, parece ser consenso que no que tange à atual situação fundiária das terras indígenas no Brasil os jurua kuéry encontram-se via de regra na posição de francos agressores e falsários: “percebi que os juruá tão criando os Mbyá 


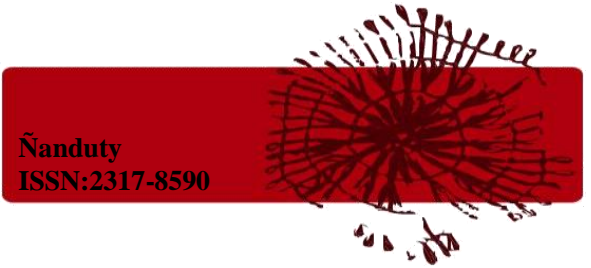

que nem galinha, assim tudo preso, do mesmo jeito do galinheiro. (...) e dão milhozinho pro Mbyá, pra ele não caminhar" (Verá Poty Benites em Pradella 2009:104). De certo modo, é como se contra os jurua (bem como contra as demais potências maléficas desta Terra) fosse preciso estar sempre em guerra.

Em 2013 após a mudança da família de Lidia de Camboinhas para Maricá, os Mbya marcaram um encontro com o prefeito desta cidade para falar sobre a questão da terra por eles ocupada, a qual já havia sido alvo de estudos por parte da FUNAI, órgão no qual o processo já tramitava desde 2009. Antes de irmos, o "coletivo de homens" (avakue) investia em pintura corporal com urucum e jenipapo, e adornos - colares, cocares, brincos, etc - dando a impressão de que iriam mesmo para uma guerra. Aliás, era nestes termos que comentavam sobre o evento, "vamos brigar" (jajoguero'a), “eu vou matar" (xee ajuka ta), eram frases repetidas por eles enquanto se aprontavam para o encontro. Ao chegarmos à prefeitura descemos da kombi $^{8}$ um bando de Mbya, alguns portando lança e/ou arco e flecha, todos pintados. Um de nós estava sem camisa e por esta razão foi impedido de entrar pelo segurança que estava na porta do prédio. Após breve discussão entre Tupã e o segurança, este aciona um superior que vem e autoriza a entrada - isso é a questão cultural deles, disse ele para o segurança. Nenhum momento de maior tensão além deste. A conversa com o prefeito e seus secretários transcorreu dentro de uma sala e enquanto Tupã, Jéka e Vera participavam da reunião, os demais aguardavam no corredor, sendo, a todo momento, requisitados para fotografias, pelos funcionários da prefeitura ou quem quer que estivesse passando por ali. A guerra se anunciou, mas não chegou efetivamente.

Contudo, alguns contextos exigiram a atualização repentina da função de guerreiro deste mesmo coletivo de homens. Certa vez alguns brancos se aproximaram da porta de entrada da aldeia de Camboinhas e começaram a trabalhar com o intuito de fincar uma grande placa de ferro com os dizeres "propriedade particular", ou seja, reivindicando a posse da terra na qual os Mbya estavam instalados há quase cinco anos. Os avakue, armados como podiam (facões, machados, enxadas, pedaços de pau, etc...), se aproximaram buscando impedir de qualquer maneira que continuassem o trabalho,

\footnotetext{
${ }^{8}$ Veículo que pode ser considerado um butim de guerra, mais especificamente da guerra com a SESAI (Secretaria de Saúde Indígena, órgão que substituiu a FUNASA no cuidado à saúde indígena), já que foi tomado da mesma sob a alegação de que, mesmo possuindo grande quantidade de veículos, o referido orgão não conduzia de forma adequada o atendimento nas aldeias do estado do Rio. A kombi ficou, então, sob os cuidados dos Mbya, e foi de grande valia quando do deslocamento do grupo de Camboinhas para Maricá, no meio do primeiro semestre de 2013.
} 


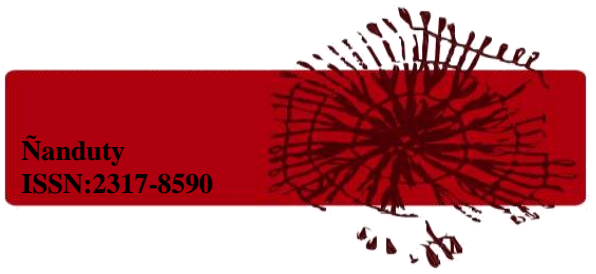

ameaçando os homens e dizendo que eles não sabiam no que estavam se metendo. Os mesmos se justificaram, dizendo que estavam cumprindo ordens, que não sabiam que havia índios ali, etc e amedrontados, tiveram que ir embora largando o serviço completamente por fazer.

Em outra ocasião entraram em conflito aberto com um jurua que por algum tempo foi amigo deles, mas que se revelou uma péssima companhia, tornando-se inimigo efetivo e definitivo deles. Guapu (como ficou sendo chamado pelos Mbya) era de São Gonçalo (município vizinho de Niterói), e se dizia policial civil, o que por si só já bastaria para impressionar os Mbya e fazer com que desejassem, nem que fosse apenas por uma questão tática, sua amizade. Ele começou a frequentar a aldeia regularmente e, não sei bem porque razão resolveu propor para os Mbya que ocupassem a duna de Itaipu, área de preservação ambiental $^{9}$, localizada em frente à aldeia, do outro lado do canal de Itaipu. Embora tal ocupação fizesse parte de um horizonte estratégico dos Mbya (para chamar a atenção da mídia para o descaso dos órgãos públicos no cuidado e na fiscalização do local) o que parecia ser o foco das intenções do tal Guapu era a expulsão dos homossexuais que utilizavam o local como ponto de encontro (com os quais os Mbya nunca haviam tido problema algum, diga-se de passagem). De fato, no dia da ocupação a homofobia explícita de Guapu se revelou muito mais violenta que o previsto: ele agrediu com um porrete cheio de espinhos (arma que ele mesmo confeccionara) um homossexual "flagrado" por ele, de modo que o mesmo foi, com a face toda ensanguentada, dar queixa no departamento de polícia militar mais próximo. Os Mbya não viram com bons olhos aquela atitude, e ainda que a ocupação da duna continuasse, a relação com ele não seria mais a mesma. Até porque, aquele jurua ainda se revelaria mais antissocial do que deixara entrever até então.

A gota d'água que faria transbordar o balde, e acabar de vez com a amizade entre os Mbya e Guapu, aconteceria numa manhã em que este, após uma noite conturbada ${ }^{10}$ acordou acusando os Mbya de roubo: dizia ele que seu "lanche" (que ele "precisava" comprar, pois na aldeia não havia janta ${ }^{11}$, e ele sentia fome de noite) do dia anterior havia

\footnotetext{
${ }^{9}$ Embora não fosse alvo de muita fiscalização por parte dos órgãos responsáveis a duna é um repositório de sambaquis e espécies vegetais nativas do mangue e da restinga. O local era aparentemente freqüentado de modo assíduo apenas por homossexuais (que deixavam espalhados pelo solo enorme quantidade do lixo resultante dos seus encontros - preservativos usados) e por usuários de drogas.

${ }^{10}$ Ele era usuário de cocaína, de modo que acontecia de às vezes perambular sem rumo pela aldeia de madrugada sabe-se lá fazendo o que.

${ }^{11}$ De fato, os Mbya preferencialmente evitam refeições noturnas.
} 
4

"sumido", e reclamava com Lidia e com Tupã. Este, que abrigava Guapu em sua casa, logo se irritou e começou a dar-lhe um esporro (-mbokavaju), dizendo que ele se irritara por causa de um "lanchinho", que ele queria "ser índio" mas não havia aprendido ainda que ali todo mundo dividia tudo, etc. Quando Guapu tentava levantar a voz, Tupã impedia - senta aí, que agora é você que vai ouvir, dizia - , até que se levantou e foi embora dizendo que Tupã era mais novo em idade do que ele e que por isso não aceitava ser tratado daquela maneira. Neste dia não foi apenas uma amizade que foi desfeita, mas uma guerra que começava, pois Guapu, aparentemente enlouquecido, se utilizava da internet para caluniar os Mbya - propagando na rede que eles teriam "alugado" a duna, dizendo que Tupã seria "mentiroso" e que Lidia seria "feiticeira", etc - e divulgar seu intento de ser defensor da duna de Itaipu, lugar onde teriam vivido seus antepassados e que, para tanto, "que o grande tamoio" decidiria o que ele iria fazer em seguida. Diante disto, e dado que até nos telejornais o caso fora parar, os Mbya começaram a acionar suas defesas: FUNAI, CCOB (Conselho Comunitário da Orla da Baía [de Guanabara]) e Polícia Federal.

Nesse ínterim, Guapu continuava a frequentar a duna de Itaipu, e numa destas visitas ele tentou expulsar uma equipe do INEA (Instituto Estadual do Ambiente) que tirava fotos no local, e os Mbya vendo isso de longe se armaram para a guerra, atualizando, num piscar de olhos, toda a potência da função xondáro. Os avakueforam rapidamente convocados e, munindo-se de todo tipo de armamento, desde facões, enxadas, pás e até pedaços de pau, se dirigiram para a duna correndo. Certamente, não foi uma cena corriqueira para os banhistas que ali se encontravam naquele dia ensolarado, ver aquele bando de índios atravessando o canal de Itaipu em direção ao outro lado, onde ficava a duna. Quando terminávamos de atravessar a água, Guapu, após praguejar rapidamente, correu para o outro lado, em direção ao asfalto onde, provavelmente, entraria em seu carro e fugiria do nosso raio de ação (outra possibilidade era que, ao alcançar o carro ele se munisse de sua arma de fogo já que, sabíamos bem, ele possuía uma, já tendo mostrado-a mais de uma vez). Os Mbya começaram a correr atrás dele, tentando cercá-lo, dando a volta na duna, mas ele conseguiu escapar. Com o fim da perseguição, nos reunimos no alto da duna, onde estava a equipe do INEA, agradecida - obrigado, disse um dos integrantes para os quais Jéka alertou, se ele voltar vai ficar enterrado aqui mesmo. O caso foi parar na Polícia Federal e alguns Mbya (bem como o próprio Guapu) foram chamados a depor, 


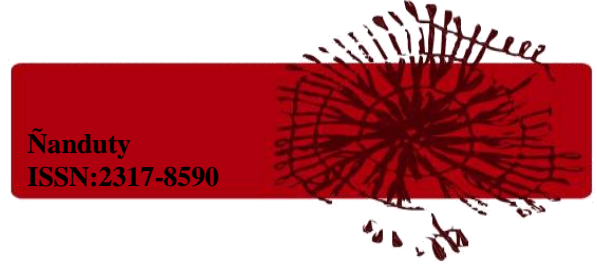

de modo que a última notícia que tivemos foi de que Guapu iria ser preso, apenas faltando, para isso, o depoimento do primeiro homossexual agredido por ele.

Se juntarmos a sentença final de Jéka com a disposição que apresentaram durante a perseguição, não poderíamos esperar um final menos do que trágico para a relação deles com este ex-amigo. Concluiremos, portanto que as pegadas do jaguar, pelo menos entre os Mbya, não estão assim tão ocultas como quer Fausto (2005:404) pois, como nota Pierri (2013) entre a maioria dos espíritos donos (e eu acrescentaria também mortos e brancos) e os Mbya o que ocorre é uma relação de predação: "se os Guarani de fato estão empenhados nisso que o autor [refere-se a Fausto] quer chamar de uma 'ética do amor' (...), é porque vivem num mundo no qual a predação está por toda parte" (:211). Para fazer convergir as propostas de Macedo (2011) e Pierri (2013), podemos por ora sugerir que enquanto a atuação de xamãs e rezadores a partir de vetores porã precisa ser regida pela piedade $\mathrm{e}$ compaixão dos deuses para com os humanos, a atuação dos xondáro a partir de vetores vai tem como pano de fundo a guerra e a predação. Vejamos agora como este tipo de tensão pode ser resolvido de outra forma, isto é, por meio da tentativa de transformar um potencial inimigo em xerimbabo.

\section{A familiarização de jurua}

Sabe-se que o contato entre índios e brancos vem acompanhado grande parte das vezes de um esforço de pacificação mútuo. Ribeiro ([1970]1996:204), por exemplo, comprova o acerto do método de aproximação de tribos hostis do antigo SPI pelo fato de este ter levado vários povos à convicção de eles é que estariam amansando os brancos. Albert e Ramos (2002) reúnem uma série de estudos sobre a pacificação dos brancos no norte da Amazônia, processo que, apresar de múltiplo, pode ser entendido de modo geral como forma de resistência política indígena diante da potência predatória da sociedade nacional. Fala-se também em "domesticar" os brancos como algo que remeteria à "teoria da relacionalidade generalizada" convencional (Kelly 2005:219): trata-se, para os brancos, de "remover artificialmente a alteridade inata, comportando-se como parente e tornando-se mais humano e moral" (idem). Era o que aparentemente estava em jogo quando da recepção de brancos na aldeia de Camboinhas, ou seja, preocupavam-se menos com o fato de estarem recebendo pessoas mbya ou jurua e mais com o fato de o visitante se 


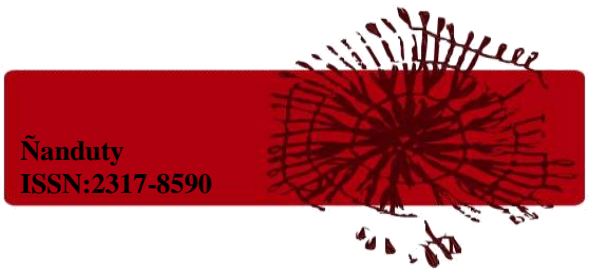

alegrar/acostumar (ovy'a) ou não ali, e para isso aqueles que chegam para ficar por algum tempo passam inevitavelmente por um processo de acomodação e adaptação no qual aprendem novos costumes, novas temporalidades e novas corporalidades. No caso dos brancos tratava-se de efetivamente de torná-los mais humanos e morais: era preciso ensinálos a ser gente, em suma.

Utilizo o termo familiarização neste contexto por achar que é possível a analogia entre os processos de amansamento de animais selvagens (para torná-los animais de estimação) e de estrangeiros, como já apontei alhures (Pereira 2016:7565). Ambos são referidos pelo termo -mbovy'a ("causar alegria" ou "fazer acostumar"), isto é, um investimento em alimentar e cuidar por parte de quem se coloque na posição de dono em relação ao termo recíproco, o xerimbabo. Pensamos aqui na relação de maestria como um “operador cosmológico" (Viveiros de Castro apud Fausto 2008:348) atuante na dimensão ontológica da ação social. Deuses são donos em relação aos humanos mbya, tal como estes o são em relação aos seus animais de estimação, ou como os pais são como donos em relação aos filhos, ou como um xondáro é dono da porta da casa de reza que vigia durante o ritual, ou como o rezador é dono de seu instrumento musical, e assim por diante. A alegria e o bem viver (teko porã) que caracterizam a humanidade mbya são dados pela manutenção desta posição perspectiva em relação aos deuses-donos ${ }^{12}$, que se atualiza de modo multilocal (em cada aldeia), mas sempre a partir de um esforço de produção de parentesco: "um não parente que chega e quer ficar é antes um parente em potencial ${ }^{13}$ que um estrangeiro. [...], numa aldeia nem todos se dizem parentes, mas devem viver como tal" (Pissolato 2007:195), ou seja, a partir de uma etiqueta que privilegia o bom humor e o “alegrar-se mutuamente" (-joguerovy'a). Poderíamos concluir assim que causar alegria em um jurua fazendo brotar nele o desejo de ficar é potencialmente produzir um parente onde

\footnotetext{
${ }^{12}$ É preciso manter-se como xerimbabo dos deuses pois o perigo de ser-se submetido ao domínio de outras subjetividades está sempre a espreita: donos de lugares na floresta, espíritos dos mortos, donos de animais etc. Retornamos ao tema do -jepota enfim, mas agora como uma conseqüência da possível mas indesejada circulação da posição de dono: ao não atualizar a relação com os deuses a pessoa abre espaço para que outrem se aproxime, ocupando a posição que era deles.

${ }^{13}$ De modo simetricamente inverso, um consanguíneo que deixa de se alegrar no convívio com a própria família, já é potencialmente um afim. Não causando alegria nos co-residentes ou não se alegrando, a pessoa pode se tornar tão antissocial quanto um animal de estimação que, indócil, "não se alegrou ainda" (ndovy'ái teri), o que é índice, em ambos os casos, de uma animalidade latente prevalecendo sobre as qualidades propriamente humanas da pessoa.
} 


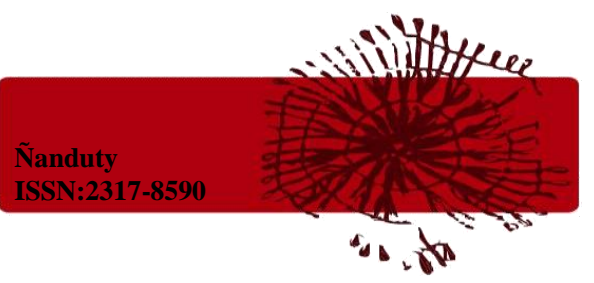

não havia nem mesmo um parente em potencial, e o gradual sucesso da empreitada é geralmente visto com muita satisfação pelos Mbya ${ }^{14}$.

Desde 2008 até o final do trabalho de campo efetivo observei algumas tentativas de familiarização de brancos que buscavam frequentar a aldeia regularmente, na maior parte das vezes do sexo masculino: eles eram então instados a estabelecer moradia, participar dos trabalhos diários, comportar-se de modo minimamente "sábio" (iarandu) ${ }^{15}$ e, no limite, casarem-se ali. Assim, quando Jéka ofereceu sua barraca de camping para Kamulaia (um pescador que havia perdido sua casa quando a favela do Morro do Bumba desabou, em Niterói no ano de 2010, e morava em sua canoa, na lagoa de Itaipu) dizendo que este poderia ficar na aldeia, o fez sob a alegação de "eu tenho pena dele" (amboaxy ixupe) o que podemos ler como o estabelecimento de uma relação de maestria na qual quem tem compaixão encontra-se na posição de dono, isto é, de quem cuida e protege seu xerimbabo: note-se que igual sentimento motivou nos deuses o desejo de conceder a Lidia seus poderes xamânicos, Nhanderu xemboaxy ("Nhanderu teve pena de mim"), explicava. Kamulaia frequentava a aldeia há algum tempo e já era bem conhecido dos Mbya quando o convite foi feito, mas se se esperava dele alguma disposição em ajudar nos afazeres diários, Kamulaia, ainda que generoso (pois trazia diariamente os peixes que pescava, dando-lhes quase em sua totalidade para Lidia) continuava a consumir cachaça regularmente, embebedando-se muito e de modo sistemático, o que caracteriza um modo "não sábio" (naiarandúi) de se relacionar com a bebida, "ele não sabe beber"16 (ndoy'u kuaái), se dizia então. Tal comportamento passou a desagradar os Mbya, os quais, todavia, não o expulsaram da aldeia, porém ao simplesmente se recusarem a dialogar com ele durante sua

\footnotetext{
${ }^{14}$ Nisso, talvez, os Mbya sejam bem parecidos com os Yudjá, para os quais "poucas coisas são tão prazerosas quanto o amansamento de humanos; poucas são tão gratificantes quanto acompanhar de perto a absorção completa das maneiras yudjá por alguém que um dia esteve destinado a viver outra vida" (Lima 2005:268).

${ }^{15}$ A oposição entre modo "sábio" e "não sábio" bem como entre "escutar" e "não escutar" o que dizem os mais velhos e as divindades já foi assim resumida: "Há (...) uma série de disposições pessoais constitutivas da sociabilidade que, partindo de "saber ouvir" (-endu kuaa) o que dizem os mais velhos e em última análise os deuses, fazem de alguém sábio, iarandu. Escutas desatentas e comportamentos anti-sociais desfazem esta possibilidade (mesmo que momentaneamente) caracterizando a pessoa como não-sábia, naiarandúi. A antisociabilidade na maioria das vezes é o início de uma transformação (em animal, em morto, etc) de modo que tal perigo precisa ser constantemente 'bloqueado' ou 'controlado' (-joko) através de dispositivos tão práticos quanto o estalar dos chicotes, sentar-se e prestar atenção ao que dizem os mais velhos, dispor-se para o trabalho diário, participar ativamente dos rituais de reza-canto, usar frequentemente o petyngua[cachimbo], entre outros" (Pereira 2016a:2). Para maiores desenvolvimentos sobre o tema ver Pereira (2014).

${ }^{16}$ Sobre o "saber beber" segundo os Mbya, ver Pereira (2016a), onde dou os primeiros passos no sentido de compreender as diferenças entre a embriaguez $\left(-k a^{\prime} u\right)$ por álcool e por tabaco. Um estudo imoprtante sobre os sentidos da embriaguez alcoólica entre os Mbya encontra-se em Heurich (2015).
} 


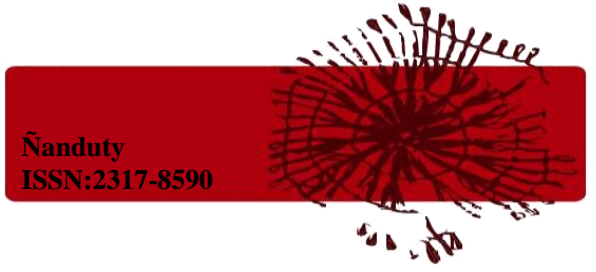

embriaguez deixaram claro seu desinteresse na continuidade da relação. A situação foi tornando-se insustentável, até que Kamulaia um dia foi embora sem comunicar nada a ninguém.

De modo diverso Bebé e Gringo, ambos jovens moradores de um bairro próximo a Camboinhas, começaram a frequentar a aldeia para jogar futebol e posteriormente também para os forrós, sendo que o primeiro logo se casou com uma neta de Lidia, estabelecendo um vínculo que dura até hoje e do qual já resultou uma criança. Quando o amigo se mudou para a aldeia, Gringo veio junto. Talvez por estar já casado, Bebé não passava pelo mesmo processo de familiarização sofrido por Gringo: fizeram-lhe pulseiras de miçangas, deramlhe, de modo quase definitivo, a função de "servir o chimarrão" (-mongay'u), ensinavamlhe os modos e etiquetas mbya, faziam-no participar dos rituais na casa de reza (inclusive ensinando-o a utilizar o cachimbo), exigiam sua participação nos trabalhos diários do coletivo de homens (construção de casas, colher e carregar sapê, etc) e assim por diante. Tanto quanto eu mesmo vinha experimentando há algum tempo quando da chegada de Gringo a Camboinhas, o corpo deste era alvo de ações no sentido de ensinar-lhe desde regras de etiqueta até procedimentos xamânicos.

Em 2008 quando conheci os Mbya de Camboinhas havia entre eles um rapaz jurua em posição semelhante a de Gringo, a não ser pelo fato de que estava casado com Kerexu: tratava-se de um nativo de Paraty Mirim, Alan, que em tudo sabia proceder como os Mbya, desde o uso do cachimbo até o uso da língua. Se Alan, mesmo casado, decidiu-se por partir, a permanência de Gringo apenas não foi mais durável devido a uma briga dele com um jurua, durante um forró dominical. Após este fato, ele parou de freqüentar a aldeia, retornado apenas muito esporadicamente, mas não deixando de ser alvo de notável afetividade por parte de Lidia, a qual sempre afirmava ter gostado muito do jeito do rapaz, já que ele "ouvia" (oendu), o que ela dizia e se dispunha a aprender o que lhe era ensinado. É preciso notar que mesmo entre Mbya kuéry o comportamento "sábio" resulta de uma valorização da capacidade de "escuta" como algo que orienta a convivência com corresidentes, mas também atualiza a conexão com os deuses. As atitudes de Gringo (bem como as de Alan e a minha) revelavam para os Mbya a possibilidade de aproximar corpos de brancos a corpos de mbya, provocando naqueles afecções características destes. $\mathrm{E}$ acrescentar afecções mbya a um corpo jurua parecia ser justamente o que orientava nossos processos de familiarização desde nossa alimentação com "comida de índio" (produzida na 


\section{0}

aldeia, entenda-se) até o cozimento de nossos $\operatorname{corpos}^{17}$ durante os rituais de reza-canto, nos quais éramos instados sistematicamente a participar. Ser familiarizado pelos Mbya não seria neste sentido algo radicalmente diverso do modo pelo qual os próprios buscam elicitar o cuidado e proteção das divindades através do posicionamento de si mesmos enquanto "animais de estimação" destas.

Contudo, algumas vezes os investimentos em familiarizar o estrangeiro mostram-se infrutífero e ele se mostra indócil e insensível aos esforços dos Mbya em torná-lo gente de fato. Foi assim com João Báia, o qual se assemelhava muito mais a um cativo de guerra do que propriamente a um xerimbabo, recebendo um tratamento capaz de oscilar rapidamente entre o cuidado e a crueldade. Ele era irmão mais velho de um amigo (vizinho e frequientador da aldeia) dos Mbya que passava por dificuldades em sua vida pessoal correndo até mesmo risco de vida por estar devendo dinheiro a traficantes de drogas, pelo que se soube na época. O irmão de Báia, então, pediu à Lidia que cuidasse dele por algum tempo, o que ela aceitou, não de muito bom grado, há que se ressaltar. Caso oposto ao de Gringo, as tentativas de educar minimamente João nos modos mbya eram quase sempre infrutíferas, pois, como se disse inúmeras vezes, ele "não sabia ouvir" (noendu kuaái) e devido a isso não era "esperto" ou "sábio" (naiarandúi). Ao encontro do que dissemos acima, o comportamento de Báia era julgado a partir de padrões próprios aos Mbya, e seu "não saber ouvir" implicava diretamente em comportamento inadequado. Báia, não raro, era vítima de modalidades efusivas de correção, como a agressão física com filetes de madeira ou bambu ${ }^{18}$, mas não era sem espanto que os Mbya o viam sempre tornar a "se fazer errar" (-nhembotavy): ele usava cocaína na aldeia, mostrava-se preguiçoso em ajudar os demais homens nos trabalhos diários e chegou mesmo a furtar dinheiro da própria Lidia. Em que pese a ajuda que dava no trabalho do bar, balcão do qual compartilhava com Pedro nos dias de forró e reggae, Báia não conseguiu de modo algum se adaptar à vida na aldeia, pelo menos, não da maneira esperada pelos Mbya. O episódio, talvez, mais humilhante para ele, foi quando, por brincadeira, deixou de servir cerveja no copo de Jéka, o qual de pronto lhe deu um violento tapa na cara, eu não tô de brincadeira com você não, vai encarar, vai encarar?, e seguiu-se outro tapa, enquanto ele não conseguia reagir, e

\footnotetext{
${ }^{17}$ Para uma análise do ritual de canto e dança guarani como cozimento corporal ver Montardo (2009).

18 O que parece agenciar Lidia (quem aplicava tais "castigos", na maioria das vezes) aqui era a função xondáro da qual falamos acima. Vilmar, de Araponga, comentou certa vez que vira seu irmão mais velho, na Argentina, se submeter a um treinamento para ser xondáro que consistia em agüentar agressões feitas com varas de bambu em suas costas.
} 


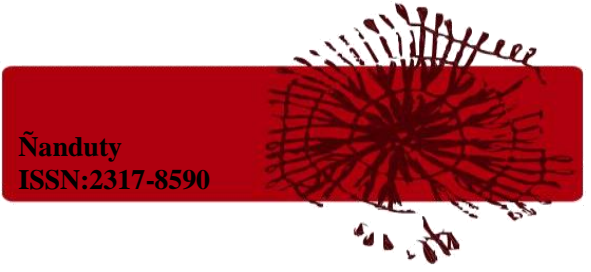

assustado somente pedia desculpas. Após o incidente, ele se lamuriava dizendo, eu não tô aqui para ser saco de pancada de ninguém não, e como já era de se esperar, como Kamulaia, certo dia ele também desapareceu dali sem maiores despedidas.

Mas a percepção da mobilidade entre aldeias do ponto de vista de quem fica (que era o nosso, em Camboinhas) está fartamente habitada por estadias (às vezes prolongadas) seguidas por partidas, de modo que alguns Mbya provenientes de outras aldeias também chegaram a Camboinhas, ficaram por algum tempo, e depois "sumiram" (okanhy), tal como Kamulaia, Gringo, Alan e Báia. Certa vez quando voltávamos de uma viagem à Paraty Mirim em uma van alugada, Xaï, um jovem mbya, pediu-nos carona até sua aldeia, Bracuí (Angra dos Reis, RJ). Como ele dormiu e os demais se esqueceram de avisar ao motorista para que parasse na referida aldeia, Xaï se deslocou conosco até Camboinhas, e como se não tivesse se tratado de um engano ficou morando ali por alguns meses. Ele trabalhava junto ao coletivo de homens e comia com eles no fogo principal, isto é, aquele abastecido por Lidia e onde atuavam como cozinheiras algumas esposas de seus filhos. Xaï não se casou em Camboinhas e sua estadia durou, ao que parece, enquanto durou sua "alegria" (-vy'a) ali. Sem muitas explicações e sob a promessa de voltar em breve, Xaï pegou carona com alguém que ia para Paraty, e por anos não voltou mais a Camboinhas.

Certa vez, Lidio, "irmão"19 de Lidia, veio do Rio Grande do Sul com a esposa e dois filhos acompanhando um xamã, do qual era "ajudante", mas depois que este seguiu viagem, permaneceu na aldeia, afinal seu pai estava morando ali. Os filhos de Lidia se referiam a ele como Karai ou Xondáro, certamente em referência à sua disposição em entrar na casa de reza e coordenar tanto o coral das crianças quanto as danças xondáro. De fato, sempre que chegávamos, ao cair da tarde, na casa ele já estava lá, da mesma forma que lá ele continuava quando nos despedíamos, após o término do ritual. Karai chegou a ter os filhos matriculados na escola da aldeia, que na época funcionava sob a administração do município de Niterói. Mas foi no meio de uma madrugada, sem avisos prévios ou despedidas de qualquer natureza, que ele e sua família atravessaram o canal de Itaipu, carregando seus poucos pertences, para entrar no carro de uma amiga jurua, que os aguardava na outra margem. Novamente, eles "sumiram" para não mais voltar.

De forma semelhante aconteceu com Jorginho, o qual foi convidado, durante uma ocasião festiva em Paraty Mirim, pelos filhos de Lidia para vir "passear" em Camboinhas,

\footnotetext{
${ }^{19}$ Em verdade, filho de Ramón, que é casado atualmente com Joventina, mãe de Lidia.
} 


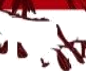

convite que foi prontamente aceito. Jorginho veio na van conosco, trazendo uma pequena mochila, com carteira, roupas e seu cachimbo. Da mesma forma que Xaï, Jorginho trabalhava junto com os demais e comia no mesmo fogo principal. Mas de forma diferente do que aquele, Jorginho acabou sendo obrigado a casar em Camboinhas, após ser flagrado "conversando" de madrugada com uma neta de Lidia, que na época devia ter uns onze anos. Como quem flagrou o casal foi a própria Lidia, seguiu-se uma "surra" (-nupã) com pedaço de bambu. A partir de tal ocasião, Jorginho “já não se alegrava mais" (ja ndovy'a véi), como se disse, e buscava sair dali de qualquer jeito, chegando até a me pedir algum dinheiro dizendo que estava "sofrendo muito". Numa manhã deu-se por consumado o que já parecia ser inevitável: Jorginho havia "sumido" durante a noite, deixando para trás sua mochila com todos os seus pertences, inclusive carteira com documentos. Os casos de Lidio e Jorginho apontam para a sugestão de Pissolato (2015:418) de que para os Mbya a fuga aparentemente é uma solução produtiva para os conflitos, que evita confrontos diretos cujos desdobramentos poderiam ser os mais desastrosos.

\section{Considerações finais}

O mundo jurua que abarca e envolve os Mbya não poderia deixar de ser absolutamente impressionante e atrativo para eles e a ferramenta que usam para experimentá-lo é corporal. Se pensarmos junto com Sant'Anna (2001:111) que "a inteligência do corpo humano é aquela dos corpos que o circundam", a experimentação adquire o sentido de um intenso engate entre corpos, de modo que a questão "o que pode um corpo?" passa a prescindir de respostas pré-definidas. Avançamos ao longo deste texto alguns passos na direção de uma resposta para os tipos de agenciamentos possíveis entre corpos de Mbya e de jurua kuéry, e enfim sugerimos que tais agenciamentos apontam para uma ética que recusa o indivíduo absoluto em favor da composição entre os corpos, algo que teria fundamental importância para a epistemologia mbya, isto é, para a ativação na pessoa de comportamentos e atitudes sábias baseadas na escuta e na percepção do que dizem os mais velhos e os deuses (ver supra nota 15).

Entre cultos e forrós, guerra e familiarização o que os brancos apresentam aos Mbya que os desperta o desejo? Para começar objetos e pessoas, coisas e corpos que possuem potência alterizadora (para usarmos expressão de Sáez 2006). Como diz Sant'anna (2001:115) "as coisas nos convidam e incitam o desejo humano com a mesma 


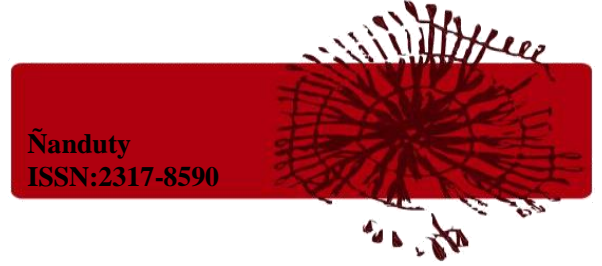

maestria que um belo corpo incita o desejo de outro", ou seja, é na relação entre corpo e desejo que a exterioridade - o Outro - é de alguma forma gerida. Ao longo de nosso breve percurso vimos os Mbya se "transformarem" em jogadores de futebol, músicos de forró, crentes, guerreiros e chegamos às tentativas de civilizar os brancos, e vimos que nunca o resultado final desta transformação é a perda de algum tipo de essência guarani. Aliás, o aspecto mais notável de tal transformação parece ser justamente sua incompletude, daí a eficiência do conceito de "devir" (cf Macedo 2013; Kelly 2005; Viveiros de Castro 1986, entre outros) para se falar dela. Caminhamos ao encontro de uma concepção espinozista de corpo na qual "a alteridade diz respeito a uma recomposição de afetos ou potências" (Macedo 2013:185). Ao longo do presente trabalho viemos tratando de alguns contextos nos quais coisas e pessoas provenientes do mundo dos jurua kuéry são capazes de despertar o desejo dos Mbya e recompôr afetos e potências em seus corpos. Considerando o modo pelo qual Macedo define o -jepota, isto é, como "a captura do desejo e a mudança no habitus de um sujeito por ação [de] um dono extra-humano" (:186), sugerimos que é justamente porque a relação com os brancos pode transformar corpos mbya (mas o contrário é igualmente verdadeiro, como vimos) que Lidia falava que ela e os seus haviam "virado jurua" (ver supra): percebia seu desejo capturado de tal modo pelo mundo dos brancos que certas mudanças em seu habitus e em seus corpos seriam já irreversíveis.

Deixamos o tema do casamento com jurua para ser tratado em outro lugar, mas convém ressaltar que embora haja um discurso de certa forma hegemônico sobre o perigo, para a pessoa mbya, de tal relação - sua alma se afastaria de seu corpo, os deuses não cuidariam mais da pessoa, a mistura de fluidos corporais (sangue principalmente) seria excessiva para o corpo mbya causando sua morte, etc - , tal discurso é permanentemente desafiado por alguns casamentos com brancos(as) duradouros que pessoas da família de Lidia vêm mantendo. Ao se casarem com jurua sem sofrer nenhum dano e, mais do que isso, mantendo ainda uma relação singular com os deuses (ver Pereira 2016) e gerando crianças mbya (e não mestiças), os Mbya com quem convivi parecem deixar claro que criaram para si um novo corpo (Pereira 2014:259), com novas potências e novas afecções. 


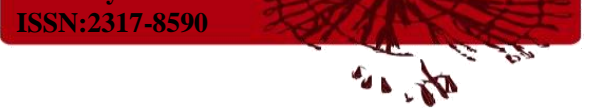

\section{REFERÊNCIAS BIBLIOGRÁFICAS}

ALBERT, Bruce \& RAMOS, Alcida Rita (orgs). Pacificando o Branco: cosmologias do contato no Norte-Amazônico. São Paulo: Editora UNESP, 2002.

CAPIBERIBE, Artionka. Batismo de fogo: os Palikur e o cristianismo. São Paulo, Annablume; FAPESP; NUTI, 2007.

CLASTRES, Pierre. Arqueologia da violência: pesquisas de antropologia política. São Paulo, Cosac naify [1980] 2004.

COSTA, Luiz. Virando Funai: uma transformação kanamari. Em Mana 22(1), 2016.

DELGADO, Ángel Acuña. Estructura y función del fútbol entre los Yanomami del Alto Orinoco. Em Revista Española de Antropologia Americana, 40(1), 2010.

FAUSTO, Carlos. Se deus fosse jaguar: canibalismo e cristianismo entre os Guarani (séculos XVI-XX). Em Mana 11(2), 2005.

HEURICH, Guilherme. Outras alegrias: cachaça e cauim na embriaguez mbyá-guarani. Em Mana, 21(3), 2015.

KELLY, José Antonio. Notas para uma teoria do "virar branco". Em Mana 11(1), 2005.

LIMA, Tania Stolze. O dois e o seu múltiplo: reflexões sobre o perspectivismo em uma cosmologia tupi. Em Mana 2(2), 1996.

. Um peixe olhou para mim: o povo Yudjá e a perspectiva. São Paulo, Editora UNESP, ISA; Rio de Janeiro, NuTI, 2005.

MACEDO, Valéria. De encontros nos corpos guarani. Em Ilha, 15(2), 2013. . Vetores porã e vai na cosmopolítica guarani. Em Tellus 11(21), 2011.

MIGLIORA, Amanda Alves. Inventando outros: desdobramentos de um contato multifacetado. Dissertação de Mestrado, Programa de Pós Graduação em Antropologia Social, Museu Nacional, UFRJ, 2014.

MONTARDO, Deise Lucy Oliveira. Através do mbaraka: música, dança e xamanismo guarani. São Paulo: Editora da Universidade de São Paulo, 2009.

PEREIRA, Levi. Significados do processo de conversão Kaiowa e Guarani ao pentecostalismo e sua inserção no cenário de inovação cultural. Em LANGER, Protasio Paulo; CHAMORRO, Graciela (orgs). Missões, militância indigenista e protagonismo indígena. XIII Jornadas Internacionais sobre as Missões Jesuíticas, Volume II, São Bernardo do Campo, Nhanduti Editora, 2012. 


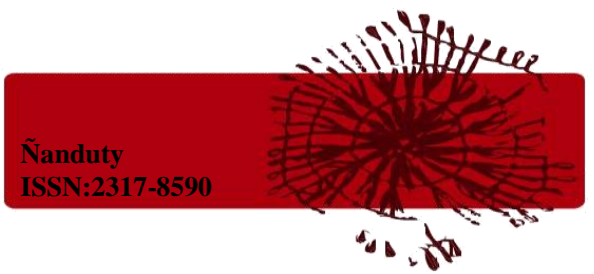

PEREIRA, Vicente Cretton. Nosso pai, nosso dono: relações de maestria entre os Mbya Guarani. Em Mana 22(3), 2016.

. O petyngua: o -ka'u como viagem xamânica. Em Anais do I Seminário de Etnologia Guarani 1(1), 2016a.

Aqueles que não vemos: uma etnografia das relações de alteridade entre os Mbya Guarani. Tese de Doutorado, Programa de Pós-Graduação em Antropologia, UFF, 2014.

Mbya reko e elementos urbanos: encontros dos Guarani Mbya com a cidade em contextos distintos de ocupação no Estado do Rio de Janeiro. Em Intratextos Numero Especial 01, 2010.

PIERRI, Daniel Calazans. O dono da figueira e a origem de Jesus: uma crítica xamânica ao cristianismo. Em Revista de Antropologia 57(1), 2014.

PIERRI, Daniel Calazans. O perecível e o imperecível: lógica do sensível e corporalidade no pensamento guarani mbya. Dissertação de mestrado, Programa de Pós-Graduação em Antropologia Social, USP, 2013.

PISSOLATO, Elizabeth. Fuga como estratégia: notas sobre sexualidade, parentesco e emoções entre pessoas mbya. Em Cadernos de Campo, São Paulo, n24, 2015.

A duração da pessoa: mobilidade e parentesco e xamanismo mbya (guarani). Rio de Janeiro: NuTI, 2007.

PRADELLA, Luiz Gustavo Souza. Jeguatá: o caminhar entre os Guarani. Em Espaço Ameríndio, 3(2), 2009.

RIBEIRO, Darcy. Os índios e a civilização: a integração das populações indígenas no Brasil moderno. São Paulo, Companhia das Letras, 1996.

SÁEZ, Oscar Calavia. O nome e o tempo dos Yaminawa: etnologia e história dos Yaminawa do rio Acre. São Paulo, editora UNESP, ISA; Rio de Janeiro, NuTI, 2006.

SANT'ANNA, Denise Bernuzzi de. Corpos de Passagem: ensaios sobre a subjetividade contemporânea. São Paulo, Estação Liberdade, 2001.

VILAÇA, Aparecida. Indivíduos celestes: cristianismo e parentesco em um grupo nativo da Amazônia. Em Religião e Sociedade, Rio de Janeiro, ISER, 27(1), 2007.

Conversão, predação e perspectiva. Em Mana 14(1), 2008.

VIVEIROS DE CASTRO, Eduardo. Metafísicas canibais: elementos para uma antropologia pós-estrutural. Cosac Naify, 2015.

. A inconstância da alma selvagem - e outros

ensaios de antropologia. São Paulo: Cosac Naify, [2002]2011.

Jorge Zahar Ed., 1986.

. Araweté: os deuses canibais. Rio de Janeiro,

WAGNER, Roy. A invenção da cultura. São Paulo, Cosac naify, 2010.

WALKER, Harry. State of play: the political ontology of Sport in Amazonian Peru. Em American Ethnologist, 40(2), 2013. 